\title{
Toxicological effect from the stem cortex of the amazonic plant soapberry Paullinia clavigera (Sapindaceae) upon three arthropods
}

\author{
Diana Pérez ${ }^{1}$, José Iannacone ${ }^{2}$, and Harvey Pinedo ${ }^{1}$ \\ 'Instituto de Investigaciones de la Amazonía Peruana (IIAP), Ucayali, Jr. Progreso 102, Pucallpa, Ucayali, Perú. \\ ${ }^{2}$ Universidad Nacional Federico Villarreal, Facultad de Ciencias Naturales y Matemática, Laboratorio de \\ Ecofisiología Animal. Av. Río de Chepén, s/n Urb. Villa Hermosa, Bravo Chico, El Agustino, Lima, Perú.
}

\begin{abstract}
D. Pérez, J. Iannacone, and H. Pinedo. 2010. Toxicological effect from the stem cortex of the amazonic plant soapberry Paullinia clavigera (Sapindaceae) upon three arthropods. Cien. Inv. Agr. 37(3):133-143. Toxicological effects of four extracts proceeding from the stem cortex of the amazonic plant Paullinia clavigera D.R. Simpson (Sapindaceae) by decoction, ethanolic, chlorophormic and hexanic on three arthropods: Rhynchophorus palmarum (Linnaeus, 1758) (Curculionidae), Eupalamides cyparissias (Fabricius, 1777) (Castniidae) and Artemia franciscana (Kellog, 1906) (Artemiidae) in Ucayali, Peru were studied. The four extracts at the highest concentration tested were: decoction at a proportion 1:10 (w/v), ethanolic, chlorophormic and hexanic at $100 \mathrm{mg} \cdot \mathrm{L}^{-1}$. Toxic effects were evaluated at 12, 24, 48 and 72 hours on larvae of III instar of R. palmarum and larvae of II instar of E. cyparissias; and at 24 and 48 hours on nauplii of $A$. franciscana. Toxicity in terms of $\mathrm{LC}_{50}$ on the three arthropods evaluated depends of type of extract of soapberry employed. In $R$. palmarum, decoction $\left(\mathrm{LC}_{50-72 \mathrm{H}}=59.15 \%\right)$ presented a high toxicity, although a significant effect of hydroalcoholic extract was observed at $40 \mathrm{mg} \cdot \mathrm{L}^{1}$ in comparison with control. The extracts of decoction $\left(\mathrm{LC}_{50-72 \mathrm{H}}=70.71 \%\right)$ and ethanolic $\left(\mathrm{LC}_{50-72 \mathrm{H}}\right.$ $\left.=66.21 \mathrm{mg} \cdot \mathrm{L}^{-1}\right)$ presented high toxicities on E. cyparissias, and finally, hexanic extracts $\left(\mathrm{LC}_{50-}\right.$ $\left.{ }_{48 \mathrm{H}}=18.79 \mathrm{mg} \cdot \mathrm{L}^{-1}\right)$, decoction $\left(\mathrm{LC}_{50-48 \mathrm{H}}=23.82 \%\right)$ and chlorophormic $\left(\mathrm{LC}_{50-48 \mathrm{H}}=23.64 \mathrm{mg} \cdot \mathrm{L}^{-}\right.$ $\left.{ }^{1}\right)$ presented the highest toxicities on $A$. franciscana. In the phytochemical analysis, saponins showed a very positive reaction in hydroalcoholic extract, and flavonoids and phenols had a very positive reaction in extract of decoction. The triterpenes were present only in the hexane extract. The hydroalcoholic and decoction extract showed toxicity on the two pest $R$. palmarum and E. cyparissias, but only the hydroalcoholic compared to the other three extracts had the lowest effect of risk and higher selectivity to the aquatic environment on A. franciscana.
\end{abstract}

Key words: Artemia franciscana, botanical insecticide, ecotoxicology, Eupalamides cyparissias, Paullinia clavigera, Rhynchophorus palmarum.

\section{Introduction}

Nowadays, products of low toxicity and low cost are required through the sustainable use of natural resources; therefore, it becomes

Received August 17, 2009. Accepted December 16, 2009. Corresponding author: joseiannacone@yahoo.es urgent to have alternative technologies in control of plague insects and diminish the use of synthetic agrochemical products contaminating and impacting the environment negatively (Iannacone et al., 2002a). The Ucayali region in the Peruvian Amazonia has a wide biodiversity of vegetal species that may be used as biocides (Pérez and Iannacone, 2006a; Iannacone et al., 2007). 
Paullinia clavigera Schldl. Var. Bullata D.R. Simpson (Sapindaceae) "Soapberry", is an endemic semi-woody vejuco (stem cortex), which is part of the primary forest and shores of South American Amazonic aquatic ecosystems (Fedon and Castillo-Suarez, 2005; Jǿrgensen et al., 2005; Weckerle and Rutishauser, 2005; Bridgewater et al., 2006; Iannacone et al., 2007; Urdampilleta et al., 2007). This species has been quoted as an ethnobiocide, as the root and the bark are used for artisanal fishing (Schultes and Raffauf, 1990). Additionally, it presents antifungal and molluscicide activity (Ekabo et al., 1996). Toxicity has been related to the presence of saponines. On the other hand, the presence of triterpens, B-sitosterol and ethereal oils is mentioned, where the ictiotoxic activity is attributed to the triterpens (Texeira et al., 1984; Gupta, 1995; Iannacone et al., 2007). A bark and root infusion is used for washing mycosis and skin wounds. It may be also taken orally after maceration in hard liquor (Vela, 2003).

Eupalamides cyparissias (Fabricius, 1777) (Lepidóptera: Castniidae) is commonly known as "bunch and stipe borer" of palm trees (Schuiling and Van Dinther, 1980). Damage is made by the larvae instars affecting inflorescences or flowering bunches resulting in reduced size and weight. When the formed or mature bunches are affected, it provokes the total or partial rot of fruits (Pérez and Iannacone, 2006b, 2008).

Rhynchophorus palmarum (Linnaeus, 1758) (Coleoptera: Curculionidae), "palm weevil" (Mexzón, 1994), causes damage by the instars larvae in the pejibaye plant, attacking the plant rhizome. In other palm trees, it forms passageways in the trunk, leaves and petioles (Vela, 2003; Pérez and Iannacone, 2006c).

Artemia franciscana (Kellog, 1906) (Anostraca: Artemiidae) is known as "brine shrimp". It is an aquatic species widely used in ecotoxicological tests as non-target organism, as it is an easily obtainable biological material with wide geographic distribution, good cultivation feasibility and inexpensive to obtain. The biotests with this species are easily to evaluate, manipulate and read (Iannacone et al., 2002b). It is used in biotests of phytochemical research for the evaluation of substances physiologically bioactive and plaguicides whose destination is the aquatic environment (Machera et al., 1996; Hlywka et al., 1997; De los Ríos and Gajardo, 2004, Gajardo et al., 2004, Cuadra et al., 2005).

The objectives of the present work were the determination of the toxicological effect of four extracts from the stem cortex of the Amazonic plant $P$. clavigera (Sapindaceae) obtained by aqueous, hydroalcoholic, chlorophormic and hexanic decoction on three arthropods: R. palmarum (Curculionidae), E. cyparissius (Castniidae) and A. franciscana (Artemiidae) in Ucayali, Peru and the characterization of the phytochemistry of the four extracts obtained.

\section{Materials and methods}

\section{Obtaining botanic extracts}

Four types of extracts of $P$. clavigera were used: aqueous extract by decoction, hydroalcoholic, hexanic and chlorophormic. The preparation of the different types of extracts of $P$. clavigera were maintained in conditions of diffused light with 32 watts $\mathrm{T} 8$ fluorescent tubes, at 25.3 $\pm 2{ }^{\circ} \mathrm{C}$ of temperature and at $77.6 \pm 3 \%$ of relative humidity. The material of $P$. clavigera was obtained from the gens bank of medicine plants and biocides in the IIAP Ucayali branch, located in the $\mathrm{Km} \mathrm{12,400}$ of the Federico Basadre highway, Pucallpa, Ucayali, Peru. The vejucos (stem cortex) were dried under direct sunlight, after their segmentation. Then, the dry vejucos were ground with a hammer mill. A 1:10 proportion was used for the preparation of the aqueous extract by decoction. The preparation was boiled for 2 hours in an electric stove, until 1L of concentrated solution was obtained $\left(250 \mathrm{~g} \cdot \mathrm{L}^{-1}\right)$. It was filtered with polysilk meshes ${ }^{\circledR}$ (Polyester, Melilla, Spain), to separate the extract of the residues. It was cooled for 2 hours. In order to evaluate the two insects from the concentrated solution, concentrations of the aqueous extracts by decoction were prepared, denominated at $100 \%\left(=100 \mathrm{~g} \cdot \mathrm{L}^{-1}\right), 75 \%\left(=75 \mathrm{~g} \cdot \mathrm{L}^{-1}\right), 50 \%(=50$ $\left.\mathrm{g} \cdot \mathrm{L}^{-1}\right)$ and $25 \%\left(=25 \mathrm{~g} \cdot \mathrm{L}^{-1}\right)$. Distilled water at pH 7 was used as control. The preparation of the hexanic, chlorophormic and hydroalcoholic 
extracts were made from $100 \mathrm{~g}$ of a dry and grounded sample in Laboratorio de Productos Naturales Antiparasitarios de la Amazonia (UNAP), Iquitos, Peru. They were extracted with hexane (apolar solvent) until they were exhausted with renovation solvent every 48 hours; the hexanic extracts were obtained after the solvent was eliminated in rotary evaporator under reduced pressure. Chlorophorm $\left(\mathrm{CHCl}_{3}\right.$, solvent moderately polar) was added to the residue until it was exhausted with solvent renovation every 48 hours, the solvent was eliminated to dryness in rotary evaporator under reduced pressure, therefore, the chlorophormic extracts were obtained. Finally, ethanol-water (70:30) (polar solvents) was added to the residue and the hydroalcoholic extracts were obtained, as in the previous cases.

$100 \mathrm{mg}$ of the heavy extract was diluted using $0.5 \mathrm{~mL}$ of hexane, $0.75 \mathrm{~mL}$ of chlorophorm and $0.45 \mathrm{~mL}$ of ethylic alcohol as dissolvent, according to the extract. The amounts of the dissolvent used in each case were different depending on the minimum $\mathrm{mL}$ for the extracts dissolution. Then, they were diluted in $1 \mathrm{~L}$ of distilled water adjusted to $\mathrm{pH}$ of 7 . The concentrations were prepared at $100 \%\left(=100 \mathrm{mg} \cdot \mathrm{L}^{-1}\right), 75 \%\left(=75 \mathrm{mg} \cdot \mathrm{L}^{-1}\right)$, $50 \%\left(=50 \mathrm{mg} \cdot \mathrm{L}^{-1}\right)$ and $25 \%\left(=25 \mathrm{mg} \cdot \mathrm{L}^{-1}\right)$. Two controls were used, the control with the maximum concentration of the dissolvent used and the absolute control with distilled water at $\mathrm{pH} 7$.

\section{Phytochemical analysis}

The phytochemical screening was made in dry and ground samples of $P$. clavigera at the Laboratorio de Investigación en Productos Naturales Antiparasitarios de la UNAP, Iquitos, Peru . Standard procedures were used for the semiquantitative phytochemical detection of nine compounds, for alkaloids (Mayer, Dragendorff and Wagner), saponins (foam production), steroids (Liebermann Burchard), triterpens (Liebermann-Burchard/Noller), tannins (gelatina-sal/ $/ \mathrm{FeCl}_{3}$ ), phenols $\left(\mathrm{FeCl}_{3}\right.$ ), flavonoids (Shinoda), coumarins (revealed with vanilla and orthophosporic acid) and quinones (Bornträger). Their presence was classified in five categories: - = negative reaction. $\pm=$ reaction very slightly positive. $+=$ reaction slightly positive. $++=$ positive reaction. $+++=$ reaction very positive (Lock, 1994)

\section{Biological material}

Rhynchophorus palmarum. Larvae of the VI to the IX instars were obtained from the Central Market of Pucallpa, Ucayali, Peru. The larvae were arranged individually in 1-liter-containers and they were fed with pieces of Bactris gasipaes Kunth (palm heart) (3.5 g.day $\left.{ }^{-1}\right)$. Four larvae were placed with food in $25 \times 15 \times 10 \mathrm{~cm}$ plastic-containers. The adults obtained were placed in couples in 1-liter-containers for mating. Distilled water was sprayed to the layings to maintain humidity. The eclosioned larvae were placed individually in $5 \times 5 \times 3 \mathrm{~cm}$ containers and they were fed with palm heart $(1.5 \mathrm{~g})$, which was renewed every two days, until reaching the III instar, which occurs eight days after the larvae eclosion (Bartra, 1994).

Eupalamides cyparissias. Adult egg-filled females were collected in $\mathrm{Km} 60$ of the Federico Basadre highway, Neshuya highway- Curimaná, Pucallpa, Ucayali, Peru. Once the females were captured, they were kept in $1 \mathrm{~m}^{3}$ plastic mesh cages, to which honey drops were added. The layings obtained were placed in petri dishes with disks of moistured paper towel. The larvae II were fed with the bunch rachis of Elaeis guineensis Jacq. (oil palm) and immature fruits.

Artemia franciscana. The cysts were obtained from an aquarium of the San Isidro district, Lima, Peru. They were cultivated until the nauplii from the II instar were obtained. The eclosion of A. franciscana followed by the procedure standardized by Iannacone et al. (2002a).

\section{Biotests}

In the case of the insects, the diet was embedded for $30 \mathrm{seg}$ in $25 \mathrm{~mL}$ for each of the four extracts. Were placed individually in 500 g-Containers with 10 repetitions per concentration. For $R$. palmarum, 10 larvae from the third instar were used per each repetition from each concentration, therefore, $3.5 \mathrm{~g}$ of pieces of palm heart were 
weighed, cut in cubes, with approximate dimensions of $2 \mathrm{~cm}$ long $x 1.5 \mathrm{~cm}$ wide $\mathrm{x} 0.5 \mathrm{~cm}$ high. For E. cyparissias, 10 larvae from the second instar were used per each repetition from each concentration. $1.5 \mathrm{~g}$ bunch rachis from oil palm were weighed, cut with approximate dimensions of $2.5 \mathrm{~cm}$ long x $2 \mathrm{~cm}$ wide $x 0.5 \mathrm{~cm}$ high. Nauplii of the II instar with less of 18 hours since the eclosion were used with $A$. franciscana. Then, 10 nauplii from the II instar of $A$. franciscana were taken to each of the 25-mL-capacity containers with $20 \mathrm{~mL}$ of solution. 10 larvae or nauplii from the second instar were used for $A$. franciscana for each of the four repetitions from each of the concentrations. The toxicity in terms of mortality was evaluated at 12, 24, 48 and 72 hours for $R$. palmarum and E. cyparissias. The evaluation for A. franciscana was at 24 and 48 hours of exposure (Calow, 1993). The biotests were made at a relative humidity of $60-85 \%$ and at a temperature of $29 \pm 2{ }^{\circ} \mathrm{C}$ for the two insects, and $25 \pm 2{ }^{\circ} \mathrm{C}$ for $A$. franciscana. The conditions and criteria of acceptability of the tests of acute toxicity were adapted from Iannacone et al. (2002a,b).

\section{Experimental design and data analysis}

The tests of acute toxicity for $R$. palmarum and E. cyparissias were evaluated in four concentrations plus two controls with solvent and control with absolute water, with ten repetitions for each concentration from each type of extract in a $6 \times 10$ completely randomized block design (CRBD). Four repetitions were evaluated for A. franciscana for each concentration from each type of extract in a $6 \times 4$ CRBD. The effectiveness of the treatments and the repetitions was evaluated through an analysis of variance (ANOVA), before the data were transformed ( $\mathrm{x}$ ) to $\sqrt{\mathrm{x}}+0.5$. The comparison of averages was made through the Test of Tukey. The estimations of the mortality corrected were made through the Abbott formula (Calzada, 1982). The data obtained were made through the pack SPSS version 12.00 (SPSS, 2004). The $\mathrm{LC}_{50}$, as well as its confidence limits (CL), the "chi-square" values and the degrees of freedom (d.f.) were determined using the EPA Probit Analysis Program (USEPA, 1994).

\section{Results}

\section{Phytochemical analysis}

The results of the phytochemical analysis from the hexanic, chlorophormic, hydroalcoholic and decoction extracts from stem cortex of $P$. clavigera are shown in Table 1. The hexanic extract presented the best reaction to the triterpens. The chlorophormic extract reacted positively to the coumarins, as with the hydroalcoholic extract to the saponins. The decoction extract presented a very positive reaction to the phenols and flavonoids, unlike the other compounds detected (Table 1).

\section{Rhynchophorus palmarum}

There not any effects on the mortality percentage of $R$. palmarum with the hexanic and chlorophormic extracts at 12, 24, 48 and 72 hours. Likewise, hydroalcoholic extract did not have effects on the mortality percentage of $R$. palmarum at 12 and 24 hours. However, different effects from the control were observed with the hydroalcoholic extract at $100 \%$ at 48 and 72 hours, although in both cases the $\mathrm{LC}_{50}$ values were higher than $100 \%$ (Table 2). The aqueous extract by decoction did not present effects at 12 hours of exposure, but significant effects were observed at 24, 48 and 72 hours in comparison with the control on $R$. palmarum. The following decreasing sequence of acute toxicity $\left(\mathrm{LC}_{50}\right)$ from the aqueous extract of $P$. clavigera on $R$. palmarum was observed: 72 hours $>48$ hours $>$ 24 hours (Table 2). At 72 hours of exposure, the following sequence of decreasing order of acute toxicity of the four extracts of $P$. clavigera on $R$. palmarum was found: aquous by decoction $>$ hydroalcoholic $>$ hexanic $=$ chlorophormic $($ Table 2). The value of the confidence limits of the $\mathrm{LC}_{50}$, the chi-square and the degrees of freedom is indicated for each period of exposure (Table 2).

\section{Eupalamides cyparissias}

Effects on the percentage of mortality of $E$. cyparissias were not found with the decoction, hydroalcoholic, hexanic and chlorophor- 
Table 1. Phytochemical characteristics of four extracts of Paullinia clavigera.

\begin{tabular}{lcccc}
\hline & \multicolumn{4}{c}{ Stem cortex extracts } \\
$\begin{array}{l}\text { Phytochemical } \\
\text { characteristics }\end{array}$ & Hexanic & Chlorophormic & Hidroalcoholic & Decoction \\
\cline { 2 - 5 } $\begin{array}{l}\text { Mass since } \\
100 \mathrm{~g}\end{array}$ & 28.38 & 45.32 & 87.58 & $1000 \mathrm{~mL}$ \\
Alkaloids & - & - & - & - \\
Saponins & - & \pm & +++ & + \\
Steroids & - & + & - & - \\
Triterpens & ++ & - & - & - \\
Tannins & - & - & - & +++ \\
Phenols & - & - & ++ & +++ \\
Flavonoids & + & + & ++ & + \\
Coumarins & - & ++ & + \pm & - \\
Quinones & \pm & \pm & ++ & + \\
\hline
\end{tabular}

Legend: - = Negative reaction; $\pm=$ Very slight positive reaction; $+=$ Slight positive Reaction; $++=$ Positive reaction; $+++=$ Very positive reaction.

mic extracts at 12 and 24 hours. Likewise, the chlorophormic and hexanic extracts did not have effects on the percentage of mortality of E. cyparissias at 48 hours, but different effects from the control were observed at 72 hours with the chlorophormic and hexanic extract at $100 \%$, although the $\mathrm{LC}_{50}$ in the chlorophormic extract was higher than $100 \%$. Additionally, the aqueous extract by decoction on E. cyparissias presented effects at 48 and 72 hours of exposure from the extract at $100 \%$, in comparison with the control. The following sequence in decreasing order of acute toxicity $\left(\mathrm{LC}_{50}\right)$ from the aqueous extract de $P$. clavigera on $E$. cyparissias was observed: 72 hours $>48$ hours (Table 2). The hydroalcoholic extract also presented effects at 48 and 72 hours of exposure of the extract at $100 \%$ in comparison with the control on E. cyparissias, although the $\mathrm{LC}_{50}$ was higher than $100 \%$ in the hydroalcoholic extract at 48 hours (Table 2). At 72 hours of exposure, the following sequence in decreasing order of acute toxicity from the four extracts of $P$. clavigera on E. cyparissias was found: hydroalcoholic $>$ aquous by decoction $>$ hexanic $>$ chlorophormic (Table 2). The confidence limits of the $\mathrm{LC}_{50}$, the chi-square value and the degrees of freedom for each period of exposure are indicated (Table 2).

\section{Artemia franciscana}

Effects on the percentage of mortality of $A$. franciscana with the decoction, hydroalcoholic, hexanic and chlorophormic extracts were detected at 24 and 48 hours. At 24 hours of exposure, the following sequence in decreasing order of acute toxicity from the four extracts of $P$. clavigera on A. franciscana was found: aquous by decoction $>$ chlorophormic $>$ hydroalcoholic $>$ hexanic. On the other hand, at 48 hours of exposure, the following sequence in decreasing order of acute toxicity from the four extracts of P. clavigera on A. franciscana was found: hexanic $>$ chlorophormic $>$ aquous by decoction $>$ hydroalcoholic (Table 2). The confidence limits of the $\mathrm{LC}_{50}$, the chi-square value and the degrees of freedom for each period of exposure are indicated in Table 2.

In $R$. palmarum, the aqueous decoction $\left(\mathrm{LC}_{50-72 \mathrm{H}}=59.15 \%\right)$ presented the highest toxicity, although the hydroalcoholic extract showed significant effects at $100 \cdot \mathrm{mg} \mathrm{L}^{-1}$. The decoction extract $\left(\mathrm{LC}_{50-72 \mathrm{H}}=70.71 \%\right)$ and the hydroalcoholic extract $\left(\mathrm{LC}_{50-72 \mathrm{H}}=66.21 \mathrm{mg} \cdot \mathrm{L}^{-1}\right)$ presented the highest toxicities in E. cyparissias. Finally, the hexanic $\left(\mathrm{LC}_{50-48 \mathrm{H}}=18.79 \mathrm{mg} \cdot \mathrm{L}^{-1}\right)$, decoction 
Table 2. Median Lethal Contrentation $\left(\mathrm{LC}_{50}\right)$ and Confidence limits of four types of extracts of Paullinia clavigera on Rhynchophorus palmarum, Eupalamides cyparissias and Artemia franciscana at several exposure periods.

\begin{tabular}{|c|c|c|c|c|c|}
\hline \multirow{2}{*}{$\begin{array}{l}\text { Type of } \\
\text { extract }\end{array}$} & \multirow{2}{*}{$\begin{array}{l}\text { Parameters and } \\
\text { statystical values }\end{array}$} & \multicolumn{4}{|c|}{ Exposure period (hours) } \\
\hline & & 12 & 24 & 48 & 72 \\
\hline \multicolumn{6}{|c|}{ Rhynchophorus palmarum } \\
\hline \multirow[t]{4}{*}{ Decoction* } & $\mathrm{LC}_{50}$ & 89.53 & 92.74 & 85.95 & 59.15 \\
\hline & $\mathrm{CL}$ & - & $83.14-103.41$ & $61.77-91.03$ & $34.97-71.88$ \\
\hline & Degree of freedom & 4 & 4 & 4 & 4 \\
\hline & Chi - cuadrado & 0.20 & 0.55 & 0.07 & 0.55 \\
\hline \multirow{4}{*}{ Hidroalcoholic } & $\mathrm{LC}_{50}$ & ND & ND & $>100$ & $>100$ \\
\hline & $\mathrm{CL}$ & ND & ND & ND & ND \\
\hline & Degree of freedom & ND & ND & 5 & 5 \\
\hline & Chi - cuadrado & ND & ND & 0,08 & 0,59 \\
\hline \multirow[t]{4}{*}{ Chlorophormic } & $\mathrm{LC}_{50}$ & ND & ND & ND & ND \\
\hline & $\mathrm{CL}^{30}$ & ND & ND & ND & ND \\
\hline & Degree of freedom & ND & ND & ND & ND \\
\hline & Chi - cuadrado & ND & ND & ND & ND \\
\hline \multirow[t]{4}{*}{ Hexanic } & $\mathrm{LC}_{50}$ & ND & ND & ND & ND \\
\hline & $\mathrm{CL}$ & ND & ND & ND & ND \\
\hline & Degree of freedom & ND & ND & ND & ND \\
\hline & Chi - cuadrado & ND & ND & ND & ND \\
\hline \multicolumn{6}{|c|}{ Eupalamides cyparissias } \\
\hline \multirow[t]{4}{*}{ Decoction* } & $\mathrm{LC}_{50}$ & ND & ND & 85.95 & 70.71 \\
\hline & $\mathrm{CL}$ & ND & ND & $61.77-91.03$ & $36.88-91.74$ \\
\hline & Degree of freedom & ND & ND & 4 & 4 \\
\hline & Chi - cuadrado & ND & ND & 0.07 & 0.55 \\
\hline \multirow[t]{4}{*}{ Hidroalcoholic } & $\mathrm{LC}_{50}$ & ND & ND & $>100$ & 66.21 \\
\hline & $\mathrm{CL}$ & ND & ND & ND & $5.68-98.60$ \\
\hline & Degree of freedom & ND & ND & 5 & 5 \\
\hline & Chi - cuadrado & ND & ND & 0.03 & 0.13 \\
\hline \multirow[t]{4}{*}{ Chlorophormic } & $\mathrm{LC}_{50}$ & ND & ND & ND & ND \\
\hline & $\mathrm{CL}$ & ND & ND & ND & ND \\
\hline & Degree of freedom & ND & ND & ND & ND \\
\hline & Chi - cuadrado & ND & ND & ND & ND \\
\hline \multirow[t]{4}{*}{ Hexanic } & $\mathrm{LC}_{50}$ & ND & ND & ND & 84.68 \\
\hline & $\mathrm{CL}$ & ND & ND & ND & $54.33-149.25$ \\
\hline & Degree of freedom & ND & ND & ND & 5 \\
\hline & Chi - cuadrado & ND & ND & ND & 0.52 \\
\hline \multicolumn{6}{|c|}{ Artemia franciscana } \\
\hline \multirow[t]{4}{*}{ Decoction* } & $\mathrm{LC}_{50}$ & $\mathrm{ND}$ & 40.88 & 23.82 & ND \\
\hline & $\mathrm{CL}$ & ND & $30.79-49.65$ & $17.15-28.86$ & ND \\
\hline & Degree of freedom & $\mathrm{ND}$ & 4 & 4 & ND \\
\hline & Chi - cuadrado & ND & 3.44 & 2.77 & ND \\
\hline \multirow[t]{4}{*}{ Hidroalcoholic } & $\mathrm{CL}_{50}$ & ND & 101.5 & 51.37 & ND \\
\hline & $\mathrm{CL}$ & ND & $87.89-141.23$ & $42.22-60.15$ & ND \\
\hline & Degree of freedom & ND & 5 & 5 & ND \\
\hline & Chi - cuadrado & ND & 1.99 & 1.49 & ND \\
\hline \multirow[t]{4}{*}{ Chlorophormic } & $\mathrm{LC}_{50}$ & ND & 91.44 & 23.64 & ND \\
\hline & $\mathrm{CL}$ & ND & $78.87-117.95$ & $6.25-35.38$ & ND \\
\hline & Degree of freedom & ND & 5 & 5 & ND \\
\hline & Chi - cuadrado & ND & 1.20 & 2.90 & \\
\hline \multirow[t]{4}{*}{ Hexanic } & $\mathrm{LC}_{50}$ & ND & 102.34 & 18.79 & ND \\
\hline & $\mathrm{CL}^{\circ}$ & ND & $84.09-161.32$ & $7.64-26.96$ & ND \\
\hline & Degree of freedom & ND & 5 & 5 & ND \\
\hline & Chi - cuadrado & ND & 0.005 & 0.08 & ND \\
\hline
\end{tabular}

$\mathrm{CL}=$ Confidence limits. Values of concentrations are in $\mathrm{mg} \cdot \mathrm{L}^{-1}($ dry weight/volumen of mother solution). ND $=$ Not determinated. $*=$ for this extract values are in percentage. 
$\left(\mathrm{LC}_{50-48 \mathrm{H}}=23.82 \%\right)$ and chlorophormic extracts $\left(\mathrm{LC}_{50-48 \mathrm{H}}=23.64 \mathrm{mg} \cdot \mathrm{L}^{-1}\right)$ presented the highest toxicity on A. franciscana.

\section{Discussion}

The toxicity of four extracts (aqueous decoction, hexanic, chlorophormic and hydroalcoholic) of the stem cortex of $P$. clavigera on three species of arthropods was evaluated in this study: two of them being land agricultural pests of relevance in the Peruvian Amazonia, the larva of Coleoptera $R$. palmarum and the larva of Lepidoptera E. cyparissias. The third arthropod, A. franciscana, is an aquatic microcrustacea used as a non-target organism. The results show differences in the toxicity of $P$. clavigera in relation to its four forms of extraction, and to the three arthropods used (Iannacone et al., 2007).

In a comparative study, Pérez and Iannacone $(2006,2008)$ evaluated the effectiveness with other nine plants, to a unique concentration of aqueous extracts of $P$. clavigera on the mortality and repellence of $R$. palmarum and $E$. cyparissias at 24 hours of exposure. In the biotests of incorporation in the diet of $R$. palmar$u m$, the results obtained in the present study at 72 hours of exposure indicate that the aqueous extract of the stem cortex of $P$. clavigera showed a significant effect in relation to the $\mathrm{LC}_{50}$ and the hydroalcoholic extract indicated a mortality of $40 \%$ at $100 \mathrm{mg} \cdot \mathrm{L}^{-1}$. The aqueous extract and the hydroalcoholic extract showed a positive reaction to phenols, flavonoids, coumarins and saponins. Only the hexanic extract showed a reaction to triterpens. Gupta (1995) mentions that the toxicity of $P$. clavigera is attributed to the presence of triterpens and saponins (Table 1). Ekabo et al. (1996) indicate antifungal and molluscicide properties of Soapberry due to the presence of the saponins. On the other hand, the hexanic and chlorophormic extracts did not show an effect in mortality at 72 hours of exposure on $R$. palmarum. Likewise, the chlorophormic extract did not show a significant effect on the mortality of $E$. $c y$ parissias at 72 hours of exposure, although it presented a very slight positive reaction saponin. This is coherent to the results obtained in the larvae from the first instar of Chrysoperla externa (Hagen, 1861) (Neuroptera: Chrysopidae) where the chlorophormic extract of the stem cortex did not produce an effect on the mortality for both in the biotests by inclusion to the diet and the tests of residual contact (Iannacone et al., 2007). However, it has been observed in Copidosoma koehleri Blanchard, 1940 (Hymenoptera: Encyrtidae) that only the hexanic extracts of stem cortex of $P$. clavigera produced significant effects on the percentage of mortality of adults and in the percentage of adult emergency (Iannacone et al., 2007).

Schultes and Raffauf (1990) indicate the presence of triterpens, $\beta$-sitosterol and ethereal oils in a plant of the same family, Serjania sp. (Jacq.) Willd (Sapindaceae), determining that triterpens are responsible of toxic activity. Molluscicide activities have been recorded in the cogeneric species to $P$. clavigera, $P$. pinnata L (Meléndez and Carriles, 2002; Iannacone et al., 2007), possibly due to flavonoids (Abourashed et al., 1999). The highest toxicity of the hexanic extract might be related to the presence of triterpens and flavonoids, where the triterpens are absent in the other three extracts. A different pattern of toxicity of the stem cortex of $P$. clavigera on the water flea Daphnia magna Strauss, 1820 (Crustacea: Daphniidae) has been determined, with the following sequence: chlorophorm $>$ hydroalcohol $>$ hexan, although the biotests were not made with the extracts by decoction (Iannacone et al., 2007). Additionally, P. clavigera showed that the aqueous extracts by decoction presented insecticide efficiency on the aquatic larvae of Anopheles benarrochi Gabaldon, Cova García and López, 1941 (Perez and Iannacone, 2004). It was found that the hydroalcoholic extracts of a congeneric species, $P$. elegans Cambess have effects against helminths and protozoan parasites (Truiti et al., 2005).

Bourgaud et al. (2001) mention that the toxicity of the secondary metabolites present in the sapindacea is generally attributed to the activity of 
saponins, phenols, flavonoids, and triterpens and in some cases to coumarins and to quinones. It was found in the present study that the four extracts of stem cortex of $P$. clavigera had a high activity on A. franciscana (Table 2) in accordance to positive reactions to flavonoids (Table 1).

The activity of crude extracts of $P$. clavigera containing numerous compounds in the biotests was evaluated; some of those compounds may be common to the aqueous, hexanic, hydroalcoholic and chlorophormic extracts (Table 1). Finally, the results show that, at 72 hours of exposure, the extracts by decoction and hydroalcoholic presented a higher activity in relation to their $\mathrm{LC}_{50}$ on the two plagues $R$. palmarum and E. cyparissias. Although the four extracts provoked a negative effect at 48 hours of exposure on A. franciscana, the hydroalcoholic extract was the least risky and with higher selectivity in the aquatic environment in comparison with the decoction, chlorophormic and hexanic extracts. Thus, as it presented high effects on the two pests and the lowest effect on A. franciscana, the hydroalcoholic formulation was the most compatible to be used in presence of water environment close to agricultural fields, which is very frequent in the Amazonic zone. This extract might be prioritary in programs of Integrated Pest Management (IPM). However, these laboratory experiments must be verified under field conditions.

The Paullinia genus is represented in the Amazonic flora, with several species of economic importance (Jǿrgensen et al., 2005; Weckerle and Rutishauser, 2005; Urdampilleta et al., 2007). The evaluation of biodiversity from the
Amazonic tropical forests reveal new biocide phytotherapeutic principles, but these studies are still under development. The biodiversity existing in the Peruvian flora is a potential source of several bioactive molecules. The most efficient botanic extracts must be priorized for the fractioning and identification of their main active components.

\section{Conclusions}

In Rhynchoporus palmarum, the following sequence in decreasing order of acute toxicity of the four extracts of $P$. clavigera was found at 72 hours of exposure: aquous by decoction $>$ hydroalcoholic $>$ hexanic $=$ chlorophormic .

In Eupalamides cyparissias, the following sequence in decreasing order of acute toxicity of the four extracts of $P$. clavigera was found at 72 hours of exposure: hydroalcoholic $>$ aquous by decoction $>$ hexanic $>$ chlorophormic.

In Artemia franciscana, the following sequence in decreasing order of acute toxicity of the four extracts of $P$. clavigera was found at 48 hours of exposure: hexanic $>$ chlorophormic $>$ aquous by decoction $>$ hydroalcoholic.

The hydroalcoholic extract and the decoction extract presented the overall highest toxicity on the two pests $R$. palmarum and E. cyparissias, but only the hydroalcoholic extract presented the lowest effect of risk and higher selectivity in the aquatic environment on $A$. franciscana, in comparison to the other three extracts. 


\section{Resumen}

D. Pérez, J. Iannacone y H. Pinedo. 2010. Efecto toxicológico de cuatro extractos de la corteza de la Planta Amazónica Sacha yoco Paullinia clavigera (Sapindaceae) sobre tres artrópodos. Cien. Inv. Agr. 37(3): 133-143. Se determinó el efecto toxicológico de cuatro extractos procedentes de la corteza de la planta amazónica Paullinia clavigera D.R. Simpson (Sapindaceae) por decocción, hidroalcohólico, clorofórmico y hexánico sobre tres artropodos: Rhynchophorus palmarum (Linnaeus, 1758) (Curculionidae), Eupalamides cyparissias (Fabricius, 1777) (Castniidae) y Artemia franciscana (Kellog, 1906) (Artemiidae). Los cuatro extractos a la mayor concentración fueron: decocción a una proporción 1:10 (p/v), hidroalcohólico, clorofórmico y hexánico a $100 \mathrm{mg} \cdot \mathrm{L}^{-1}$. El efecto tóxico fue evaluado a 12 , 24, 48 y $72 \mathrm{H}$ sobre las larvas del III estadío de $R$. palmarum y larvas del II estadío de $E$. cyparissias; y a 24 y $48 \mathrm{H}$ sobre los nauplios de A. franciscana. La toxicidad en términos de $\mathrm{CL}_{50}$ en los tres artrópodos evaluados dependió del tipo de extracto de Sacha yoco empleado. En $R$. palmarum, la decocción $\left(\mathrm{CL}_{50-72 \mathrm{H}}=59,15 \%\right)$ presentó una alta toxicidad, aunque el hidroalcohólico presentó efectos significativos a $40 \mathrm{mg} \cdot \mathrm{L}^{-1}$, en comparación al control. Los extractos por decocción $\left(\mathrm{CL}_{50-72 \mathrm{H}}=70,71 \%\right)$ y hidroalcohólico $\left(\mathrm{CL}_{50-72 \mathrm{H}}=66,21 \mathrm{mg} \cdot \mathrm{L}^{-1}\right)$ presentaron altas toxicidades en E. cyparissias, y finalmente, los extractos hexánico $\left(\mathrm{CL}_{50-48 \mathrm{H}}\right.$ $\left.=18,79 \mathrm{mg} \cdot \mathrm{L}^{-1}\right)$, por decocción $\left(\mathrm{CL}_{50-48 \mathrm{H}}=23,82 \%\right)$ y clorofórmico $\left(\mathrm{CL}_{50-48 \mathrm{H}}=23,64 \mathrm{mg} \cdot \mathrm{L}^{-}\right.$ $\left.{ }^{1}\right)$ registraron las mayores toxicidades sobre A. franciscana. En el análisis fitoquímico, las saponinas presentaron reacción muy positiva en el extracto hidroalcohólico, y los flavonoides y los fenoles tuvieron reacción muy positiva en el extracto por decocción. Los triterpenos sólo se encontraron presentes en el extracto hexánico. El extracto hidroalcohólico y el de decocción mostraron toxicidad sobre las dos plagas $R$. palmarum y E. cyparissias, pero sólo el hidroalcohólico, en comparación a los otros tres extractos, mostró el menor efecto de riesgo y de mayor selectividad en el ambiente acuático sobre $A$. franciscana.

Palabras clave: Artemia franciscana, ecotoxicología, Eupalamides cyparissias, insecticida botánico, Paullinia clavigera, Rhynchophorus palmarum.

\section{References}

Abourashed, E.A., N.J. Toyang, J. Jr. Choinski, and I.A. Khan. 1999. Two new flavone glycosides from Paullinia pinnata. Journal of Natural Products 62: 1179-1181.

Bartra, P.C. 1994. Manual de crianza de algunos insectos benéficos a la agricultura peruana. Sociedad entomológica del Perú, Lima, Perú. 57 pp.

Bourgaud F, A. Gravot, S. Milesi and E. Gontier. 2001. Production of plant secondary metabolites: a historical perspective. Plant Science 161: 839851.

Bridgewater, S.G.M., D. J. Harris, C. Whitefoord, A.K. Monro, M.G. Penn, D. A. Sutton, B. Sayer, B. Adams, M. J. Balick, D. H. Atha, J. Solomon, and B. Holst. 2006. A preliminary checklist of the vascular plants of the Chiquibul forest, Be- lize. Edinburgh Journal of Botany 63: 269-321.

Calow, P. 1993. Handbook of ecotoxicology. Vol. I. Blackwell Science Ltd., Sheffield, UK. 478 pp.

Calzada, B. 1982. Métodos estadísticos para la investigación. $5^{\circ}$ Ed. Edit. Milagros. UNALM. Lima, Perú. 644 pp.

Cuadra, P., M. Furrianca, A. Oyarzún, E. Yánez, A. Gallardo, and V. Fajardo. 2005. Biological activity of some Patagonian plants. Fitoterapia 76: 718-721.

De los Ríos, P., and G. Gajardo. 2004. The brine shrimp Artemia (Crustacea: Anostraca): a model organism to evaluate management policies in aquatic resources. Revista Chilena de Historia Natural 77: 3-4.

Ekabo, O., N. Farnswoth, T. Henderson, G. Mao, and R. Mukherjee. 1996. Antifungal and molluscicidal saponins from Serjania salzmanniana. Journal 
of Natural Products 59: 431-435.

Fedon, I. C., and A. Castillo-Suárez. 2005. Angiospermas trepadoras de los bosques ribereños de una sección de la cuenca baja de los ríos CuaoSipapo (Estado Amazonas, Venezuela). Acta Botánica Venezuelica 28: 7-38.

Gajardo, G., J. Crespo, A. Triantafyllidis, A. Tzika, A.D. Baxevanis, I. Kappas, and T.J. Abatzopoulos. 2004. Species identificación of chilena Artemia populations based on mitocondrial DNA RFLP analysis. Journal of Biogeography 31: 547-555.

Gupta, M. 1995. 270 Plantas Medicinales Iberoamericanas. Talleres de Editorial Presencia Ltda. Santa Fé de Bogotá, Colombia. 617 pp.

Hlywka, J.J., M.M. Beck, and L.B. Buillerman. 1997. The use of the chicken embryo screening test and brine shrimp (Artemia salina) bioassays to assess the toxicity of fumonisin B1 mycotoxin. Food and Chemical Toxicology 35: 991-999.

Iannacone, J., L. Alvariño, and J. Mansilla. 2002a. Actividad insecticida de cuatro extractos botánicos sobre larvas de los mosquitos Culex quinquefasciatus (Díptera: Culicidae) y Chironomus calligraphus (Díptera: Chironomidae). Wiñay Yachay 7: 56-71.

Iannacone, J., L. Alvariño, and G. Lamas. 2002b. Evaluación del riesgo ambiental del insecticida botánico rotenona empleando cuatro invertebrados de la biota animal. In: Mazzoleni, R.C., F.X. Souto, L.A. Lacava y J.R.R. Braun (eds.). XXIV Congreso Brasileiro de Zoología: A Zoología e os Ecosistemas Costeiros. 17 a 22 de fevereiro de 2002. Itajaí - Santa Catarina. p. 644.

Iannacone, J., L. Alvariño, J.C. Soto, and C. Salcedo. 2007. Efecto toxicológico del "Sachayoco", Paullinia clavigera (Sapindaceae) sobre Daphnia magna y sobre dos controladores biológicos de plagas agrícolas. Journal of Brazilian Society of Ecotoxicology 2: 15-25.

Jǿrgensen, P.M., M.J. Macía, A. Fuentes, S.G. Beck, M. Kessler, N. Paniagua, R. Seidel, C. Maldonado, A. Araujo-Murakami, L. Cayola, T. Consiglio, T.J. Killeen, W.H. Cabrera, G.F. Bascopé, D. De la Quintana, T. Miranda, F. Canqui, and V. Cardona-Peña. 2005. Lista anotada de las plantas vasculares registradas en la región de Madidi. Ecología en Bolivia 40: 70-169.

Lock, O. 1994. Investigación Fitoquímica: métodos de estudio de productos naturales. Pontificia Universidad Católica del Perú. Fondo Editorial.
Lima, Perú. 300 pp.

Machera, K., E. Cotou, and P. Anastassiadou. 1996. Fenbutatin acute toxicity on Artemia nauplii: effects sublethal concentrations on ATPase activity. Bulletin of Environmental Contamination and Toxicology 56: 159-164.

Meléndez, P.A., and V.A. Carriles. 2002. Molluscicidal activity of plants from Puerto Rico. Annales of Tropical Medicine and Parasitology 96: 209-218.

Mexzón, R.G. 1994. Manejo integrado de artrópodos perjudiciales en el cultivo del pejibaye (Bactris gasipaes K.B.K) y sus enemigos naturales. In: M. Urpi (ed.). Palmito del Pejibaye. Universidad de Costa Rica. San José, Costa Rica. p. 138-145.

Pérez, D., and J. Iannacone. 2004. Efecto insecticida del Sacha yoco (Paullinia clavigera var. bullata Simpson) (Sapindaceae) y oreja de tigre (Tradescantia zebrina Hort ex Bossé) (Commelinaceae) en el control de Anopheles benarrochi Gabaldon, Cova García y López, 1941, principal vector de malaria en Ucayali, Peru. Ecología Aplicada 3: 64-72.

Pérez, D., and J. Iannacone. 2006a. Efectividad de extractos botânicos de 10 plantas sobre la mortalidad y repelencia de larvas de Rhynchophorus palmarum L., insecto plaga del pijuayo Bactris gasipaes Künth en la Amazonia del Peru. Agricultura Técnica (Chile) 66: 21-30.

Pérez, D., and J. Iannacone. 2006b. Comportamiento e infestación de Eupalamides cyparissias (Fabricius) (Lepidóptera: Castniidae) en palma aceitera (Elaeis guineensis Jacquin, Areacaceae) en la Amazonía peruana. Revista Peruana de Entomología 45: 135-137.

Pérez, D., and J. Iannacone. 2006c. Aspectos de la bioecología de Rhynchophorus palmarum (Linnaeus) (Coleóptera: Curculionidae) en el pijuayo (Bactris gasipaes H.B.K.) (Arecaceae), en la Amazonía peruana. Revista Peruana de Entomología 45: 138-140.

Pérez, D., and J. Iannacone. 2008. Mortalidad y repelencia en Eupalamides cyparissias (Lepidoptera: Castniidae), plaga de la palma aceitera Elaeis guineensis, por efecto de diez extractos botánicos. Revista de la Sociedad Entomológica Argentina 67: 41-48.

Schultes, R.E., and R.F. Raffauf. 1990. The healing Forest. Discorides Press, Portland, Oregon, USA. 410 pp. 
Schuiling, M., and B.M. Van Dinther. 1980. Ecology and control de Castnia daedalus, a major pest of oilpalm in Brazil. Zeitschrift fuer Angewandte Entomologie 9: 161-174.

SPSS - Statistical Package for the Social Sciences. 2004. SPSS Base 12.0 User's Guide for Windows. SPSS Inc., Chicago, Illinois, USA. Available online at: http:// www.spss.com/spss (Website accessed: 21 December, 2007). 400 p.

Teixeira, J., A. Lapa, C. Souccar, and J. Valle. 1984. Timbós: ichthyotoxic plants used by Brazilias Indians. Journal of Ethnopharmacology 10: 311-318.

Truiti, M.C., I.C. Ferreira, M.L. Zamuner, C.V. Nakamura, M.H. Sarragiotto, and M.C. Souza. 2005. Antiprotozoal and molluscicidal activities of five Brazilian plants. Brazilian Journal of Medical and Biological Research 38: 1873-1878.

Urdampilleta, J.D., M.S. Ferrucci and A.L.L. Vanzela. 2007. Cytogenetic studies of four South
American species of Paullinia L. (Sapindaceae). Botanical Journal of Linnean Society 154: 313320.

USEPA. 1994. User's guide: Probit Program version 1,5. U.S. Environmental Protection Agency (USEPA). Ecological Monitoring Research Division, Cincinatti, Ohio, USA. 14 pp.

Vela, C. 2003. Efecto de diez extractos vegetales en laboratorio, para el control de Castnia dedalus Cramer, insecto plaga en palma aceitera Elaeis guineensis J. y Rhynchophorus palmarum L. en pijuayo para palmito Bactris gasipaes H.B.K.- Pucallpa. Tesis Ingeniero Agrónomo. Universidad de Ucayali. Pucallpa, Perú. $162 \mathrm{pp}$.

Weckerle, C.S. and R. Rutihauser. 2005. Gynoecium, fruit and seed structure of Paullinieae (Sapindaceae). Botanical Journal of Linnean Society 147: 159-189. 
